\title{
A Case of Fatal Pyothorax in a Stone Marten Caused by a Grass Awn and Streptococcus canis
}

\author{
I. LITERÁK ${ }^{1}$, J. KLIMEŠ ${ }^{1}$, R. HALOUZKA ${ }^{2}$, J. SMOLA $^{3}$ \\ ${ }^{1}$ Department of Biology and Wildlife Diseases, Faculty of Veterinary Hygiene and Ecology, \\ ${ }^{2}$ Department of Pathological Morphology, \\ ${ }^{3}$ Department of Microbiology nad Immunology, Faculty of Veterinary Medicine, \\ University of Veterinary and Pharmaceutical Sciences, Brno, Czech Republic
}

Received April 4, 2002

Accepted March 25, 2003

\section{Abstract}

Literák I., J. Klimeš, R. Halouzka, J. Smola: A Case of Fatal Pyothorax in a Stone Marten Caused by a Grass Awn and Streptococcus canis. Acta Vet. Brno 2003, 72: 111-113.

A stone marten (Martes foina) with unusual behaviour had been observed near a tourist chalet in the Kralický Sněžník Mountains (Czech Republic) in the spring 2001. A fresh cadaver of probably the same stone marten was found near the chalet 24 days following this observation. A grass awn was found postmortally in the pulmonary parenchyma and purulent pneumonia with pyothorax was diagnosed. Streptococcus canis (group antigen G) was isolated en masse from the affected pulmonary parenchyma. The death was caused by grass awn aspiration resulting in purulent pneumonia and pyothorax. This is the first report of $S$. canis in a stone marten.

Aspiration, foreign body, Martes foina, Mustelidae, pleuritis, pneumonia, Streptococcus canis

\section{Case report}

On May 13, 2001 a marten with unusual behaviour was observed near a tourist chalet in the Kralický Sněžník Mountains (northern part of the Czech Republic). The chalet is an isolated building on a meadow surrounded by extensive spruce forests at an altitude of approximately $900 \mathrm{~m}$ above sea level. The marten was observed for about half an hour during the day. It was not shy; its eyelids were partly closed, panting and movement incoordination were observed while neither nasal nor oral discharge were noted. The same animal or other martens with similar unusual behaviour were also repeatedly observed in the same area in April and between May 18 and June 6, 2001.

On June 6, 2001 at 4 p.m., a fresh cadaver of a marten was found near the chalet. Tourists walking across the site shortly before the finding did not notice any dead animal. Rigor mortis was present at the time of finding. The cadaver was transported to diagnostic laboratory during the same night and post-mortem examination was performed next day; samples for routine histologic, bacteriologic, and virologic examination were collected.

The adult male stone marten (Martes foina) was considerably emaciated. At necropsy, some $30 \mathrm{ml}$ of greenish-grey liquid was found in the thoracic cavity. The pulmonary and thoracic pleura was diffusely thickened by greenish-grey layer. Also the mucosa of the trachea and large bronchi had green-grey colour. A foreign body - grass awn measuring approximately $15 \mathrm{~mm}$ - was found in the pulmonary parenchyma. This grass awn penetrated through the pulmonary parenchyma and pleura into the pleural cavity. Mediastinal lymph nodes were enlarged. The liver consistency was firmer than normal. No gross lesions were noted in other organs. The following lesions were found on histopathologic examination of HE-stained preparations: fibrinous-purulent pleuritis, pyothorax, purulent and gangrenous bronchopneumonia, acute purulent mediastinal lymphadenitis, and liver congestion.

Address for correspondence:

Prof. MVDr. Ivan Literák, CSc., Department of Biology and Wildlife Diseases,

Faculty of Veterinary Hygiene and Ecology,

University of Veterinary and Pharmaceutical Sciences,
Palackého 1-3, 61242 Brno, Czech Republic
Phone ++420-5-41562525

Fax: ++420-5-743020

http://www.vfu.cz/acta-vet/actavet.htm 
On bacteriologic examination, samples of lung tissue and exsudate collected from pleural cavity were cultured. After 24 hours of aerobic culture at $37^{\circ} \mathrm{C}$, massive growth of colonies characteristic of beta-haemolytic streptococci was observed on sheep blood agar (Oxoid, Basingstoke, UK) and Mac Conkey's agar (Oxoid). Microscopic examination revealed $\mathrm{G}+$ cocci in chains; further properties such as negative catalase test and positive $\mathrm{O}-\mathrm{F}$ test confirmed the classification of the strain as a member of the genus Streptococcus. Based on biochemical examination using commercial tests such as Api Strept (BioMérieux, France) and Streptotest 16 (Pliva-Lachema, Brno, Czech Republic), the strain was determined as Streptococcus canis. Demonstration of group antigen was performed by co-agglutination and gel precipitation. Because of the high degree of strain autoagglutination, the determination of group antigen by co-agglutination technique was not possible. The strain was therefore extracted by standard technique by Fuller and extract was examined by double gel diffusion using commercial streptococcal sera produced by SEVAC (Czech Republic). This examination resulted in precipitation line between extract and Lancefield's group $\mathrm{G}$ antiserum whereas reactions with sera against group antigens $\mathrm{C}$ and $\mathrm{L}$ were negative. The strain isolated en masse from pulmonary tissue and exsudate was thus identified as typical S. canis with Lancefield's group $\mathrm{G}$ antigen.

The virologic examination aimed at rabies and distemper diagnosis yielded negative results.

\section{Discussion}

The stone marten is a wild carnivore which is only exceptionally spotted during the day, although it often lives in or near human dwellings. The observation of a stone marten with unusual behaviour during the day, gives clues to the possibility of infectious disease. Regarding the risks of transmission to humans, the first step is to confirm or exclude rabies. In this case the possibility of rabies was excluded by specific examination. The necropsy demonstrated foreign body aspiration as a cause of disease. The grass awn aspiration was followed by its penetration through pulmonary parenchyma. The tissue injury resulted in inflammation in whose pathogenesis Streptococcus canis (Lancefield's group $\mathrm{G}$ antigen) played a major part in addition to putrefactive organisms. This agent could only colonize marten's upper airways originally and it was subsequently introduced into the pulmonary parenchyma by the penetrating awn. The immediate cause of death was respiratory failure.

It is likely that the marten which had emerged at the tourist chalet on May 13, 2001 was the same individual that died here on June 6,2001. If this was the case, the affected marten survived full 24 days. Other unusual observations of martens in that area obviously had no association with the described case.

The grass awn aspiration is a well-known cause of canine disease (Brennan and Ihrke 1983; Lotti and Niebauer 1992) and it was also reported in cats (Marascaux 1995). In the available literature we found only one mention of grass awn aspiration in stone marten (Geisel 1992).

The name $S$. canis was originally used for group $\mathrm{G}$ streptococci isolated from dogs and this species was unequivocally characterized as late as in 1986 (Devriese et al. 1986). To date it has been proven not only in canine infections but also in infections in humans, cats, and harbour porpoises (Phocoena phocoena) (Devriese et al. 1986, 1989; Clemets on and Ward 1990; Jeps on et al. 2000). We were unable to find any data in the available literature on the occurrence of $S$. canis in stone marten or other members of the weasel family (Mustelidae). Nevertheless, unspecified streptococci have been reported earlier, including cases of pleuritis and focal suppurative pneumonia in two stone 
martens (Sabolic 1980). Geisel (1992) found beta-haemolytic streptococci in martens suffering from pleuritis, pneumonia of miscellaneous etiology, endocarditis, septicaemia and subcutaneous phlegmone.

\section{Smrtelný pyothorax u kuny skalní způsobený travní osinou a bakterií Streptococcus canis}

Na jaře roku 2001 byla u horské turistické chaty v pohoří Kralický Sněžník pozorována kuna skalní (Martes foina) s neobvyklým chováním. Za 24 dní po tomto pozorování byla před chatou nalezena čerstvě uhynulá kuna skalní. Jednalo se pravděpodobně o stejného jedince, u kterého zde bylo toto neobvyklé chování pozorováno dříve. Postmortálně byla $\mathrm{u}$ této kuny zjištěna travní osina $\mathrm{v}$ plicním parenchymu a diagnostikovaná purulentní pneumónie a pyothorax. Z postiženého plicního parenchymu byl masivně izolován Streptococcus canis (skupinový antigen G). Úhyn kuny byl způsoben vdechnutím travní osiny, které vyústilo v purulentní pneumónii a pyothorax. Poprvé je popsán výskyt $S$. canis u kuny skalní.

\section{Acknowledgements}

This study was supported by Grant No. 161700001 of the Ministry of Education, Youth and Sports of the Czech Republic.

\section{References}

BRENNAN, KE, IHRKE, PJ, 1983: Grass awn migration in dogs and cats: a retrospective study of 182 cases. J Am Vet Med Assoc 182: 1201-1204

DEVRIESE, L, CEYSSENS, K, HOMMEZ, J, VANDERMEERSCH, R, 1989: Occurrence of Streptococcus canis infection among dogs, and cats and cattle (in Dutch with English summary). Vlaamsk Diergeneesk Tijdschr 58: 11-13

DEVRIESE, LA, HOMMEZ, J ,KILPPER-BALZ, R, SCHLEIFER, KH 1986: Streptococcus canis sp. nov.: a species of group $\mathrm{G}$ streptococci from animals. Int J Syst Bact 36: 422-425

GEISEL, O 1992: Die Krankheiten von Steinmarder Martes foina (Erxleben, 1777) und Baummarder Martes martes (Linné, 1758) unter besonderer Berücksichtigung pathologischer Organbefunde. Adv Vet Med (Suppl. J Vet Med) 43. Paul Parey Scientific Publishers. Berlin and Hamburg, 134 p.

JEPSON, PD, BAKER, JR, KUIKEN, T, SIMPSON, VR, KENNEDY, S, BENNETT, PM, 2000: Pulmonary pathology of harbour porpoises (Phocoena phocoena) stranded in England and Wales between 1990 and 1996. Vet Rec 146: 721-728

LÄMMLER, C, GUSZCZYNSKI, T, DOBRYSZYCKA, W, 1990: Characterization of haptoglobin-binding properties of Streptococci of serological group G. Zbl Bakt 274: 70-77

LOTTI, U, NIEBAUER, GW, 1992: Tracheobronchial foreign bodies of plant origin in 153 hunting dogs. Comp Cont Educ Pract Vet 14: 900-904

MARESCAUX, L 1995: Cas clinique. Point Vétérinaire 26: 78-79

SABOLIC, M, 1980: Todes- und Krankheitsursachen beim Steinmarder (Martes foina) in Baden-Württemberg Einzugsgebiet Staatliches Tierärztliches Untersuchungsamt Aulendorf. Thesis, Ludwig-MaximiliansUniversität München, 64 p. 